\title{
Revisiting trade unions' response to new public management: a case from Zambia
}

\author{
Clever Madimutsa and Leon G. Pretorius
}

\begin{abstract}
This article discusses the strategic responses by public-sector unions to new public management (NPM) reforms in Zambia. The article is based on a qualitative research methodology focusing on the Civil Servants and Allied Workers Union of Zambia. The study shows that public-sector workers in developing countries are more vulnerable to the effects of externally imposed NPM reforms, which include job cuts. However, the implementation of these reforms faces opposition especially from trade unions. In line with the assumptions of strategic choice theory, union responses to NPM reforms are strategic. Despite the high vulnerability of public workers in developing countries, their unions use strategies that can also be observed in developed countries to mitigate the negative consequences of NPM reforms on the public sector. These strategies follow a three-stage process, namely, opposing the reforms, negotiating for favorable reform measures, and shifting from centralized structures to networks.
\end{abstract}

\section{Introduction}

The public sector the world over has been undergoing reform since the 1980s. The reforms have taken two forms. The first is new public management (NPM) while the second is postNPM reforms (Christensen \& Lægreid, 2007). In general terms, the reforms attempt to promote efficiency and effectiveness of public institutions by adopting private-sector strategies. These include downsizing, restructuring, human resource management, decentralization, outsourcing, commercialization, performance management, and partnerships (Ayee, 2008; Dzimbiri, 2008).

The NPM paradigm originated in developed countries, particularly in the United Kingdom. From the United Kingdom, it moved to the United States, Australia, and New Zealand. Later on, it moved to Scandinavia and Continental Europe. Eventually, every country in the world got influenced by this paradigm in one way or another (Lane, 2000). However, this paradigm presents significant challenges for democratic governance (Edigheji, 2008; Manning, 2001; Zafra-Gómez, Bolívar, \& Muñoz, 2012). It also affects the employment relationship in the public sector. The effects include job losses and reductions in union membership and income (Anderson, Griffin, \& Teicher, 2002; Brewster, Dempsey, \& 
Hegewisch, 2001). The other effect is promotion of industrial conflict (McDonald \& Pape, 2002).

The negative effects of reforming the public sector force trade unions to make strategies to adapt to the changing circumstances. Kochan, Katz, and McKersie (1994) argue that when they get affected by the reform of industrial relations, trade unions and other key actors make strategic decisions to achieve their goals. According to Kochan et al., strategic decisions are made at three levels of industrial relations activity. These are policy-making, collective bargaining, and workplace levels. Union strategies at policy-making level include political, representation, and organizing strategies. At collective bargaining level, the focus of unions is on bargaining strategies. At work-place level, unions make strategies relating to employment contracts, employee participation, and the design of jobs (Kochan et al., 1994). Martin (1997) identifies 14 issues that trade unions focus on in the context of public-sector reform. These are being offensive, dialogue, values and objectives, diversity, leadership and employee empowerment, efficiency, employment security, flexibility, incentives, performance measurement, career development, ethics, training, and equal opportunities.

The literature shows that despite being put in a difficult situation, trade unions are able to respond strategically to the reform of the public sector. They do so both before and after the implementation of the reforms. Before the implementation of the reforms, unions respond by opposing them. This strategy was used in France (Pollitt \& Bouckaert, 2011). The unions can also decide to participate in the process of setting the reform agenda for the benefit of their members. This strategy has been used in Australia (Connoley, 2008). After implementation, trade unions can make strategic decisions to mitigate the effects of the reforms. There are various options at this stage. Brewster et al. (2001) state that European trade unions responded to the reform of the public sector by forming mergers and alliances both in the public and private sectors and decentralizing their structures. Similar responses have been reported in Australia (Anderson et al., 2002). The other responses by unions in Europe include using electronic systems to recruit members, delivering various services to members, and enhancing communication between members and the leadership (Waddington, 2005). Like their counterparts in the developed world, trade unions in developing countries respond strategically to economic and institutional reforms. Webster (2006) indicates that trade unions in South Africa responded to the liberalization of the economy and informalization of work by trying to control outsourcing, mobilizing casual workers, and organizing informal workers. These strategies have also been tried in Nigeria and Ghana (Andrae \& Beckman, 2011). However, the literature on public-sector reform and trade unions is not comprehensive. It is based mainly on the experiences of developed countries especially those in Australasia, Europe, and North America. There is little evidence of how trade unions in developing countries respond to various types of reforms. These countries include those in Africa, Asia, and South America. Trade union response in these countries might be different from the developed world because of the different levels of democratization and economic development between the two worlds. Unlike the developed world, developing countries are characterized by weak governance structures. Reform measures in these countries are also susceptible to external control especially from 
international financial institutions. This is done through conditions attached to external means of financial aid (Heeks, 1998). Because of these conditions, public-sector workers are more vulnerable in developing countries. Therefore, it is important to understand how public-sector unions in these countries maintain their role and respond to the adverse effects of NPM on workers. This article attempts to provide this information based on a case from Zambia. This case is relevant because it focuses on reforms that are not decided by the government but externally imposed by international financial institutions.

To achieve its purpose, the article investigates the Civil Servants and Allied Workers Union of Zambia (CSAWUZ) under the rubric of NPM reforms. This study is relevant because it helps to understand the strategies of union survival under difficult circumstances especially in developing countries where poverty levels are high. The remainder of this article is organized as follows. The "NPM and Its Political and Organization Consequences" section presents an overview of the NPM paradigm and its political and organization consequences. The "Research Methodology" section explains the methodology used to conduct the research. The "Implementation of NPM in Zambia and Its Effects on the Public Sector" section analyzes the manner in which NPM reforms were introduced and implemented in Zambia and their effects on the public sector. The "Effects of NPM on the CSAWUZ" section examines how the implementation of NPM affected the CSAWUZ. This examination focuses on two major areas of public-sector unionism. These are union structure and governance. The "Strategic Responses by the CSAWUZ to NPM Reforms" section discusses the strategic decisions made by the CSAWUZ to deal with the negative effects of NPM reforms. This discussion is centered on decisions made in five key areas. These are participation in the reform process, membership recruitment, union objectives, collective bargaining, and union governance. Finally, the "Conclusion" section presents the conclusion of this article.

\section{NPM and Its Political and Organization Consequences}

NPM was the main paradigm in the last two decades of the 2oth century. Its features were first outlined by Hood (1991). These include performance-based rewards, public tendering, decentralization, cost saving, flexibility, and antitrade union practices (Hood, 1991). Anderson et al. (2002) reveal that economic theories such as public choice and agency theories provided the theoretical foundations of NPM. These theories emphasize the application of private-sector principles to the management of public institutions. These principles are embraced because of the argument that private-sector mechanisms raise efficiency in the provision of goods and services (Lane, 2000).

While NPM emphasizes efficiency, it has several political and organizational consequences. These include reduced access to information, lack of political accountability, and variation in service delivery (Edigheji, 2008; Manning, 2001; Zafra-Gómez et al., 2012). These consequences are triggered by the implementation of neoliberal policies such as decentralization and privatization. The implementation of these policies entails the transfer of power, responsibilities, and resources from the center to lower levels of government and from the government to the private sector. This leaves politicians with little control over 
policy-making and service delivery. In turn, workers and the general public are left without social and economic protection. They are exposed to job cuts, wage freeze, and a high cost of living. As a result, there are political upheavals (Simutanyi, 1996).

The size of the public sector is also negatively affected by the implementation of NPM reforms. Simutanyi (2011) indicates that the breakdown of state-owned enterprises (SOEs) in Zambia has led to several job losses. This problem is also experienced in other African countries that have lost skilled workers through the processes of downsizing and privatization (Omoyefa, 2008). This, in turn, affects the quality of the public sector. Pollitt and Bouckaert (2011) argue that frequent downsizings demotivate and decrease the expertise of the public service in particular and the government in general. In addition, NPM makes the public sector lose important sources of revenue. Mwambwa, Griffiths, and Kahler (2010) reveal that the Zambian government has failed to raise enough revenue from the privatized mines because of tax exemptions given to foreign investors. Against this background, public-sector unions play a crucial role in mediating the negative consequences of NPM reforms on public-sector employees. The present study analyzes this role by studying public-sector union responses to NPM in Zambia.

\section{Research Methodology}

The research adopted a qualitative methodology. It focused on gathering in-depth information on the effects of NPM reforms on public-sector unions in Zambia and the unions' response to the same reforms. The field of NPM is chosen because it represents the first generation of public-sector reform (Christensen \& Lægreid, 2007). Two types of data were collected. These are secondary and primary data. On one hand, documents focusing on NPM reforms and employment relationship were used as sources of secondary data. These included books, journal articles, research reports, working papers, and conference papers. On the other hand, the sources of primary data were original program documents, Acts of Parliament, and constitutions and leaders of the CSAWUZ. The CSAWUZ was selected because it had the largest membership among public-sector unions in Zambia in the 1990 s (Koyi, 2010) when NPM reforms gained momentum. As such, it offers more insights into the effects of NPM reforms on public-sector unions and their response to the same reforms.

A sample of six leaders of the CSAWUZ was used as an additional source of primary data. The sample comprised four former and two current leaders. Five of these leaders were males while one was female. The leaders were selected from the national, regional, and branch levels of the union's organizational structure. The sampled leaders were located in Lusaka, the capital city of Zambia. The research used a sample of six union leaders because it was difficult to select a larger sample. Leaders who served during the NPM era (i.e., 1980s-1990s) could not easily be located due to the fact that most of them were retirees and their current locations were not known.

The union leaders were selected using the snowball sampling method (SSM), also known as chain-referral sampling. Using this method, each leader who was contacted was requested to 
mention the names, whereabouts, and/or mobile phone numbers of their colleagues. The sample was then chosen from the located leaders. The SSM was used because it is the most appropriate method to use when dealing with hidden populations including those in conflict environments that are characterized by mistrust (Cohen \& Arieli, 2011). The method of semistructured interviews was used to collect data from the sampled union leaders. The shortest interview was $29 \mathrm{~min}$ while the longest $70 \mathrm{~min}$. The period within which the interviews were conducted was from January 27 to February 24, 2015.

To some extent, the use of a qualitative methodology and snowball sampling could have threatened the internal and external validity of the research. The threats included the possibility of the informants straying from the subject of discussion and the informants not having an equal chance of being sampled. However, efforts were made to minimize the effects of these threats. First, the interviewers ensured that the informants stuck to the subject of discussion. Second, the responses were examined to ensure that they were logically linked to each other. Third, efforts were made to ensure that all the three key levels of the union's organizational structure were represented in the sample. These are national, regional, and branch levels.

\section{Implementation of NPM in Zambia and Its Effects on the Public Sector}

The NPM reforms were introduced to Zambia through the adoption of the Structural Adjustment Program (SAP) in 1983. Apart from addressing economic and administrative problems facing the country, SAP was also a condition to access financial support from international financial institutions, mainly the International Monetary Fund (IMF) and the World Bank (Simutanyi, 1996). Detailed strategies to reform the public sector were presented in the early 1990s. These were contained in the Privatization Act and the Public Service Reform Program. The major reform strategies included privatization, restructuring, performance management, and decentralization. Privatization emphasized the sale of SOEs (Republic of Zambia, 1996). Restructuring focused on reducing the size of the public service through measures such as streamlining of organizational structures, hiving off certain departments, and retrenchment of workers. In the case of performance management, its purpose was to improve the performance of the public service by implementing measures like open performance appraisal, training, and improved remuneration. As for decentralization, it involved the transfer of some functions from the center to lower levels of government (Republic of Zambia, 1993).

The main reason for adopting the reforms was to reduce the size and cost of the public sector. In 1993, the size of Zambia's public service was "estimated at about 180,000, comprising about 75,000 Civil Servants, 26,000 Local Authority Employees, about 45,000 non-joint Council Employees and 34,000 Classified Daily Employees" (Republic of Zambia, 1993, p. 10). The country also had more than 280 SOEs (Krishna, 2006) with more than 100,000 employees (Simutanyi, 2011). This size of the public sector was considered to be very large and too expensive to manage. The other reason for adopting the reforms was to improve the performance of the public sector in particular and the economy in general. Before the reforms, there were several public complaints about the performance of the 
public sector. These included failure to deliver basic services such as health, education, transport, and infrastructure to the people (Republic of Zambia, 1993).

The external imposition of the reforms made it difficult for the government to implement them. There were protests against the reforms from various sections of society. These included members of the public who engaged in demonstrations and riots. Trade unions also protested through public announcements and strikes. These protests forced the United National Independence Party (UNIP) one-party government to abandon SAP in 1987 (Simutanyi, 1996). This kind of opposition to externally imposed reforms is comparable with advanced democracies. Greeks had similar protests against austerity measures imposed by the European Union, the IMF, and the European Central Bank (Sakellaropoulos \& Sotiris, 2014). However, these protests are not adequate to prevent the implementation of externally driven reforms. This is because the reform process relies largely on the willingness of the government. While the UNIP government failed to implement SAP in Zambia in the 1980s, the Movement for Multiparty Democracy (MMD) government managed to do so in the 1990 under a multiparty political system.

The implementation of NPM reforms in Zambia led to a major reduction in the scope of the public sector. By December 1999, a total of 235 SOEs had been privatized (Zambia Privatisation Agency, 1999). This was one of the most comprehensive privatization programs in Africa. Furthermore, the restructuring process resulted in massive job losses. Between 1993 and 2000, Zambia's public service was reduced from 180,000 to 104,000 employees (Republic of Zambia, 2005). This means that almost half of the workforce was retrenched. This also means that the role of the government in the processes of production and distribution of goods and services was drastically reduced. As such, the private sector had an opportunity to actively participate in economic activities. In addition, the strategy of decentralization led to the fragmentation of the public sector. This was due to the creation of independent institutions to deliver services on behalf of the central government. These institutions included education and health boards, which operated at national, district, and community levels (Momba, 2006). This kind of transformation also fragmented the membership of public-sector unions. This shows that the unions had failed to oppose the reforms. Therefore, the only option at their disposal was to make strategic decisions to mitigate the effects of the reforms. So, what were the unions' responses after the implementation of NPM reforms? This is the question this article attempts to answer.

\section{Effects of NPM on the CSAWUZ}

The transformation of the public sector under the rubric of NPM affected two major areas of public-sector unionism. These are union structure and governance. These effects are examined below.

\section{Effects on Trade Union Structure}

The term trade union structure may be defined as "those sections of the labour force which a given organization seeks to recruit" (McCarthy, 1985, p. 125). According to McCarthy (1985), trade unions use different patterns of membership recruitment. These include 
confining their recruitment to specific occupations, industries, sectors, or organizing over a very large area. At the time of its formation in 1976, the Civil Servants Union of Zambia (CSUZ), now CSAWUZ, assumed the structure of what we call a "specific-sectoral" union. The term "specific-sectoral" union may refer to a union that organizes in a particular subsector of the economy. In this regard, the CSUZ organized civil servants, who are a subcategory of workers in the public sector. Civil servants are defined in terms of nonmilitary employees of the central government who are engaged on permanent and pensionable terms of employment. The informants mentioned that the workers in this category include administrative officers, print assistants, personnel officers, registry clerks, accountants, accounts assistants, accounts clerks, nurses, and laboratory technicians, among others. A former president of CSAWUZ mentioned that the CSUZ was formed because "there was no union to represent the civil servants." This was in spite of other government workers such as teachers having a union to represent them, namely, the Zambia National Union of Teachers. So, the civil servants "felt strongly that they also needed a union in order to advocate for improved conditions of service" (Former President, CSAWUZ). This observation reveals that the reason for forming the CSUZ was in line with the main function of trade unions across the world (see Bendix, 2010; Salamon, 2000). Based on this function, the CSUZ managed to attract a substantial number of members. By 1995, it had 65,000 members (Koyi, 2010).

However, the implementation of NPM reforms had a negative impact on the membership base of CSUZ. The measures of streamlining organizational structures, hiving off some departments, and retrenchment of workers led to a significant loss of union membership. As the CSUZ had confined its recruitment to civil servants, it lost membership of employees who were separated from the civil service. Between 1995 and 2001, the membership of CSUZ reduced from 65,000 to 36,000 (Koyi, 2010). This represented a membership decline of $44.6 \%$. This kind of membership decline is similar to what happened in developed countries such as Australia (Anderson et al., 2002) and European countries (Brewster et al., 2001). This finding also shows that confining union membership to a specific category of workers weakens the union when such workers begin to lose employment due to restructuring measures.

\section{Effects on Union Governance}

The effects of NPM reforms were also felt in the area of union governance. The term union governance relates to the management of union activities and relationships. It includes the roles of the leadership and the membership in directing union activities, and the extent to which union policies and decisions reflect the interests of the membership (Salamon, 2000). The governance process of the CSUZ was affected by reductions in membership and subscriptions. With fewer members paying subscriptions, the union had less money for its operations. One informant stated,

Like [in the] Ministry of Health, we used to collect a check of [Zambian Kwacha] 90,000 a month. But when these reforms came, as you are saying, it came drastically sometimes to [Zambian Kwacha] 30,000 . . . So that means it affected even our day by day 
administration. It was affected because our budget was brought down from what we anticipated. (Former Regional Secretary, CSAWUZ)

The loss of jobs in the public sector also affected the quality of the union leadership and its ability to serve the interests of the general membership. Due to job losses, there was increased workload for those who remained in employment. By virtue of being workers, trade union leaders were also overworked by their employers such that they were unable to effectively perform union functions. An informant at branch level indicated,

The members had to work hard and because some of the union members were nurses just like myself, it was difficult to find time to do branch work and again come back and work in the ward because sometimes I would find myself alone on duty. So, it was difficult to run the affairs of the union because of the shortage [of staff]. (Former Chairperson, Women's Committee, CSAWUZ)

The inability of the union to serve the interests of the membership, such as protecting jobs and reducing the workload, led the general membership to lose confidence in the union leadership in particular and union activities in general. A trustee at branch level observed that, at some point, employees felt that they were better off without a union because their employer, the government, was able to do whatever it wanted, whether the union was against it or not. These observations imply that restructuring of the public sector prevents trade unions from performing their traditional functions, thereby allowing public-sector employers to exploit workers.

The reforms also affected the relationship between the labor movement and the government. Rather than maintaining a cordial relationship, conflict of interest started to emerge between the two parties. The conflict was centered on issues of employee separation and compensation. A former president of CSAWUZ stated that the government wanted to transfer all the health workers from the central government to the Central Board of Health (CBoH; a newly established autonomous institution) without compensating them. The argument presented by the government was that the issue of compensation would also be transferred to $\mathrm{CBoH}$. This approach was rejected by the CSUZ, which wanted the workers to be paid their dues before being transferred to the new employer. In spite of the objection by the union, government did not change its position. This forced the union to take legal action to protect workers' interests. According to the former president of CSAWUZ, "around 1995 . . the Civil Servants Union [of Zambia] decided to go to court to prevent government from transferring the health workers without paying them what they had accrued as benefits." This observation indicates that trade unions, on their own, are not strong enough to compel the government to honor its contractual obligations in the midst of reforms. Instead, they need external support especially court intervention. This strategy has been used successfully by some unions in other countries. The Australian Services Union (ASU) took legal action against the implementation of Compulsory Competitive Tendering (CCT) and managed to secure benefits for employees (Connoley, 2008). 
Not only did the Zambian government want to separate workers from central government employment without compensation, but it also threatened them with punishment if they did not comply. This escalated the conflict between the two parties. A former president of CSAWUZ indicated that the union viewed the government as being untruthful in the reform process. He mentioned,

Because they were saying if people migrated from central government to the Central Board of Health, their conditions of service will be better . . But the way government was doing it was more like blackmail. Like those who remain with the government will have nowhere to work. Because they said if you don't move to central board then where are you going to work because government will have no hospitals? (Former President, CSAWUZ)

The Zambian government used force in combination with the "divide and rule" strategy to weaken the unions and drive its agenda for reform. This was illustrated by government efforts to encourage the formation of splinter unions. A former president of CSAWUZ observed that the "architect" of the formation of the Zambia National Union of Health and Allied Workers was Mr. Michael Sata, then Minister of Health. The informant indicated that Mr. Sata "actually confessed that it was his idea that there should be a union just for health workers because they were a special group" (Former President, CSAWUZ). This observation reveals that NPM reforms enabled management in particular and the government in general to undermine the power of trade unions in the process of managing workers in the public sector.

Intra- and interunion conflicts were heightened by the establishment of autonomous institutions, which facilitated the formation of new trade unions to represent their workers. The informants stated that Zambia Revenue Authority Workers Union was formed to represent workers at the Zambia Revenue Authority. The Zambia National Union of Health and Allied Workers was also formed to represent workers in health boards. A new union was also formed to represent workers in trades training institutes and colleges. Intraand interunion conflicts were due to the problem of poaching of members. One informant mentioned,

So the Zambia National Union of Health and Allied Workers was formed. And that union, primarily, they were supposed to target workers employed by the boards. But they began straying and trying to recruit even those who were employed by the central government. So some hostilities started arising between the Civil Servants Union and the Zambia National Union of Health and Allied Workers. (Former President, CSAWUZ)

The problem of strained relations within and between unions was also experienced in Australia when the CCT policy was introduced (Connoley, 2008). This finding supports Streeck and Visser (1997) who indicate that open and expansive unionism increases interunion competition, "with all unions poised in principle to claim jurisdiction in any economic sector and to enter the territory, actual or potential, of any other union" (p. 326). 
How then did the CSUZ respond to the effects of NPM reforms? This question is answered in the next section.

\section{Strategic Responses by the CSAWUZ to NPM Reforms}

Having failed to fight against the reform of the public sector, the CSUZ made strategic decisions that would help to mitigate the negative effects of the reforms on its members. This approach was in line with strategic choice theory which argues that the key actors affected by the reform of industrial relations (i.e., employers, trade unions, and government) make strategic choices to achieve their goals (Kochan et al., 1994). The strategic decisions of the CSUZ were in five key areas. These are participation in the reform process, membership recruitment, union objectives, collective bargaining, and union governance. The details of these decisions are discussed below.

\section{Participation in the Reform Process}

The CSUZ decided to participate in the process of formulating the reform strategies to protect workers' interests. The participation took the form of meetings between the union and the government. The meetings were held at national and institutional levels. At national level, the union met with the central government, while at institutional level, union representatives attended management meetings. In these meetings, the union took the approach of challenging government proposals and presenting alternatives. For instance, instead of focusing on the reduction of the workforce, the labor movement was interested in identifying the most appropriate level of employment in the public sector and embarking on rightsizing as opposed to downsizing. An informant stated,

So for us, we instead came with a counter proposal of rightsizing rather than downsizing because the government was emphasizing on downsizing. As a union, our emphasis was on rightsizing where we felt that the numbers were insufficient, we should endeavor to increase the numbers. Where the numbers were more than the requirement to operate optimally, then we can reduce. (Former President, CSAWUZ)

The strategy of participating in the reform process to protect the interests of workers was also used by the ASU in response to the reform of the local government in Australia (Connoley, 2008). This finding supports Martin's (1997) argument that when trade unions fail to oppose the reforms, they should get involved in the reform process. Nonetheless, their involvement should not be at the expense of employees' welfare. Instead, the unions should keep on fighting for better terms and conditions of employment. In case of job loss, the unions should negotiate for a good compensation package. One informant mentioned,

On voluntary separation, what we opposed was just the package because it was lower than what these people should actually [have] been given had everything been taken in accordance with the conditions of service . . . We insisted that we go by what the Employment Act provided for, the severance package. (Former President, CSAWUZ) 


\section{Membership Recruitment}

Following the reduction in union membership due to downsizing of the public sector, the CSUZ decided to increase its membership by adopting various strategies of the organizing and servicing models of recruitment. Under the organizing model, the first strategy was to change the structure of the union from a "specific-sectoral" union to a general-sectoral union. This meant that rather than being confined to a specific sector, it extended its recruitment to related fields (Hughes, 1966). In this regard, instead of being limited to civil servants, the CSUZ extended its recruitment to allied workers. The allied workers included those "in the Zambian Public Service and grant aided institutions and employees of government departments turned [into] parastatal bodies and organizations, Boards, Authorities, Agencies and Nongovernmental Organisations" (CSAWUZ, n.d., p. 1). The second strategy was to change the name of the union from CSUZ to CSAWUZ. This change was made in 2002 so that the name of the union could reflect the change in its structure. The new name showed that the union was organizing not only civil servants but also allied workers. As noted above, allied workers included those in semiautonomous government institutions and nongovernmental organizations. The third strategy was to actively involve union members in the recruitment process. An informant stated,

We instructed branches to keep an eye to [identify] new employees. Because every day, public service employs and sends these civil servants in various ministries . . . So those are new members who do not belong to any union. Then it is the work of the branch to recruit the new members then report to us as Regional Secretary. (Former Regional Secretary, CSAWUZ)

Under the servicing model, the strategy was to offer both financial and nonfinancial services to members. These included loans and training (Former Chairperson, Women's Committee, CSAWUZ). These models of recruitment have also been adopted by trade unions in developed countries such as Australia (see Anderson et al., 2002) and European countries (see Waddington, 2005). However, these strategies are not effective if membership recruitment is confined to workers in a declining sector. This was the case with CSAWUZ, which concentrated on the organization of workers in the civil service whose scope was reducing. For instance, despite the CSAWUZ adopting the above-mentioned strategies, its membership continued to decline. Between 2001 and 2010, its membership reduced from 36,000 to 17,000 (Koyi, 2010). This represented a membership decline of $52.8 \%$.

\section{Union Objectives}

The other area where strategic decisions were made involved the objectives of the union. Before the implementation of NPM reforms, the CSUZ set itself to achieve the following objectives:

a) The organisation of Civil Servants employed by the Zambian Government in order to pursue and protect the general and individual interests of its members.

b) To seek for and safeguard reasonable salaries and conditions of employment. 
c) The improvement of the standards and status of the Civil Service.

d) The encouragement of sympathy and understanding between the Government and its servants.

e) To mediate in dispute between Government and its employees, between one member and another and between members and other workers so as to secure an amicable settlement whenever possible.

f) Co-operation with other trade unions.

g) To provide members with financial assistance during prolonged and unpaid sick leave subject to the financial position of the Union permitting.

h) To advance members' education through workers' education programmes.

i) To encourage members' participation in national development programmes.

j) To do all such other lawful things as are related to or lead to the achievement of all the above objects or any one of them. (CSUZ, 1985, pp. 2-3)

The data presented above indicate that before the implementation of NPM reforms, the CSUZ was performing traditional functions of trade unions. These include promoting and protecting the interests of workers in a particular sector, industry, or occupation. Nevertheless, this approach to trade unionism is not good enough to serve the interests of workers in a reforming public sector. This is because of the changing structure of the public sector. The public sector is no longer centralized but decentralized. Therefore, the CSUZ made a strategic decision to adjust its objectives after the implementation of NPM reforms. The major adjustments were in two areas. The first focused on increasing the categories of members to protect. In this regard, the union started to organize both civil servants and allied workers. This strategy was important because it had the potential of attracting new members from hived-off institutions. The second adjustment focused on the enhancement of gender equality (CSAWUZ, n.d.). This strategy was significant because it gave the union an opportunity to attract female members who had become key participants in the labor market. This approach to trade unionism has been observed in other countries. Pitcher (2007) shows that trade unions in Africa and Latin America are now dealing with nontraditional matters affecting various categories of workers.

\section{Collective Bargaining}

The CSAWUZ also made strategic decisions in the area of collective bargaining. The first strategy was to conduct research before presenting items for collective bargaining. This strategy required the engagement of experts in research methodology. As such, the union decided to recruit a degree holder especially in economics to be in charge of its Directorate for Research. The research was to focus on gathering information on the performance of the 
global economy, performance of the national economy, the cost of living in the country, inflation rate, and comparison of pay structures of various institutions, among others. Based on this information, the union would then come up with its items for collective bargaining (Former President, CSAWUZ).

The second strategy was to increase the number of bargaining units. As opposed to having one bargaining unit covering the interests of all civil servants, the union decided to have two. One bargaining unit covered the interests of health workers only while the other was for the rest of the civil servants. According to a former president of CSAWUZ, this strategy was necessitated by government's desire to improve the remuneration of health workers without doing the same to other categories of civil servants. He mentioned,

So the idea was really to challenge government to say, look, if you really want the health workers to have a better pay than what they are getting now, you can still give them even when they are working under the central government. (Former President, CSAWUZ)

The above-mentioned strategies had both positive and negative consequences. By having two bargaining units, the CSAWUZ was able to secure gains for one category of its members while others lost out. A former president of CSAWUZ indicated that in the year 2003, when this strategy was launched, "the government gave higher salary increments for the health workers." This observation shows that the strategy of dividing union members into several bargaining units enables the union to negotiate for conditions of service that meet the needs of particular categories of employees (Zagelmeyer, 2007). For instance, this strategy enabled improved conditions of service to be secured for health workers in Zambia. However, this strategy has the weakness of promoting variations in the terms and conditions of employment (Schnabel, Zagelmeyer, \& Kohaut, 2006). As mentioned above, this strategy enabled health workers to have better conditions of service than the rest of the civil servants in Zambia. This strategy, therefore, divides workers and reduces their bargaining power. This in turn enhances the exploitation of workers.

\section{Union Governance}

The CSAWUZ also made strategic decisions concerning its governance process. Changes were made regarding the union's organizational structure and strategies to influence public policy-making. Before the implementation of NPM reforms, the CSUZ had a decentralized organizational structure. Under this structure, union powers and duties were distributed among various organs of the union. These included Quadrennial Conference, Annual Delegates Conference, Extraordinary Delegates Conference, National Executive Council, Disciplinary Committee, Branch Meeting, and Branch Committee. The Quadrennial Conference was the highest ranked organ of the union while the Branch Committee was the lowest. The Quadrennial Conference was composed of National Executive Council members, Disciplinary Committee members, Provincial Workers Educators, and two members of each Branch Committee (CSUZ, 1985). 
To some extent, the CSUZ was governed according to democratic principles such as membership participation in union matters and election of leaders. Apart from employees of the union, like the Workers' Education Secretary and Provincial Workers Educators, all other positions in the union were elective for a 4-year term of office. At branch level, members were empowered to hold two types of meetings. The first type was the general meeting that was held "at least once every three months or more frequently should circumstances demand" (CSUZ, 1985, p. 31). The second type was the Annual General Meeting, which was held to, among others, elect the Branch Committee. A branch or its committee had the power to act in a manner aimed at promoting or protecting the interests of its members (CSUZ, 1985).

The CSUZ also had lines of accountability. The Annual Delegates Conference had the duty of providing appropriate guidance to the National Executive Council for the purposes of governing the union in the period between the Quadrennial Conferences (CSUZ, 1985). This finding supports Hyman (1975) who posits that trade unions "explicitly incorporate a twoway system of control" (p. 73, emphasis in original]). He asserts that sometimes union officials are allowed to control the members while other times the members are allowed to control the officials. However, this type of organization was inadequate to deal with the challenges presented by NPM reforms such as massive job losses and reductions in union membership, income, and bargaining power. As such, the CSAWUZ attempted to strengthen itself by reforming its organizational structure after the implementation of NPM reforms. The first reform measure was to reduce the number of conferences held in the period between the Quadrennial Conferences. This was achieved by abolishing the Annual Delegates Conference and replacing it with the Biennial Conference (CSAWUZ, n.d.). The Biennial Conference was held after a period of 2 years, and its duties were similar to those of the abolished Annual Delegates Conference (CSAWUZ, n.d.). This reform measure was important because it helped the union to reduce operational costs. At that time, the union could not afford to hold several delegates conferences because its financial base had been eroded.

The second reform measure involved some changes to the composition of the National Executive Council. The changes included replacing the title of National Chairman With President, replacing the title of Vice National Chairman With Deputy President, abolishing the positions of Assistant General Secretary (Administration) and Assistant General Secretary (Finance), and introducing the position of Deputy General Secretary (CSAWUZ, n.d.). These changes reveal that the union attempted to mimic the structure of the government, which was headed by the President. The changes also reveal that the union had made efforts to downsize. Instead of having two officials assisting the General Secretary (i.e., Assistant General Secretaries), there was one (i.e., Deputy General Secretary). This kind of reform was significant as it meant that the union could reduce its wage bill.

The third reform measure was the establishment of new organs of the union. These included Women's Committees at national and branch levels, Women's Quadrennial Conference, and positions of Regional Secretary and Shop Steward (CSAWUZ, n.d.). The composition, power, 
and functions of these organs were as follows: The Women's Committee at national level consisted of seven members led by the Chairperson. The functions of this committee were as follows:

i.To organize women's affairs in all Branches;

ii.To promote unity and understanding among female members of the Union;

iii.To advise the National Executive Council on problems of working women and assist in the effective implementation of related recommendations and resolutions;

iv.To co-operate with other women bodies in the Trade Union Movement and other specialized women organisations locally and internationally. (CSAWUZ, n.d., p. 10)

The function of the Women's Committee at branch level was to handle matters affecting women in line with the instructions given by the National Executive Council and the Women's Committee at national level. As for the Women's Quadrennial Conference, it was made up of members of the Women's Committees at both national and branch levels (CSAWUZ, n.d.). The establishment of organs to deal with women matters was significant for the union. These organs offered the union an opportunity to attract female members and to promote networks within the union and between the union and other stakeholders. This, in turn, had the potential to enhance the collective strength of the labor movement. The position of Regional Secretary was established at provincial level. The Regional Secretary had the duty of coordinating the activities of the branches in the province (CSAWUZ, n.d., pp. 11-12). This was relevant because it promoted networking within the union and strategic use of union resources. This type of organizational structure has been observed in some European unions that have been trying to balance between the needs of leadership and democracy (see Hyman, 1994).

The position of Shop Steward was established at ministerial, departmental, or section level. The functions of the Shop Steward included membership recruitment and organization as well as attending to issues affecting members at that level (CSAWUZ, n.d.). The creation of this position was important because it brought union services closer to the membership. This type of organizational reform is similar to the way some trade unions in the United Kingdom such as UNISON responded to the reform of the public sector (see Brewster et al., 2001).

The fourth reform measure was the reduction in the number of members required to form a union branch. Before the implementation of NPM reforms, branches of CSUZ could be formed in every place with 200 or more members (CSUZ, 1985). Nevertheless, after the reforms, this number was reduced to 100 (CSAWUZ, n.d.). This measure made it easier for union branches to be formed. It also reduced the number of members to be served by each branch. This, in turn, enabled union organs to get closer to the membership. In addition, the workload of the leadership at branch level was reduced. This action was vital considering that 
union leaders were also required to attend to their duties as public servants. However, the formation of new branches put pressure on union resources, which negatively affected its operations. This implies that NPM reforms put public-sector unions in a dilemma.

The other area where the CSAWUZ made strategic decisions following the negative effects of NPM reforms was its influence on public policy-making. The union attempted to increase its influence by collaborating with other unions. This was done through its federation, the Zambia Congress of Trade Unions. In this regard, whenever the Zambia Congress of Trade Unions was invited to participate in the formulation of a public policy, it requested its affiliates (to which the CSAWUZ was a member) to make contributions. A former president of CSAWUZ stated that the Zambia Congress of Trade Unions used this strategy to participate in the formulation of the National Development Plan. The use of this strategy was important because it enabled the labor movement to mobilize collective resources to promote the interests of its members. This strategy is similar to what has been adopted by some trade unions in Europe (see Hyman, 1994).

\section{Conclusion}

The implementation of NPM reforms has resulted in major political and organizational changes in the public sector especially in developing countries. Unlike developed countries, reform measures in developing countries are susceptible to external control mainly from international financial institutions, which attach conditions to their financial aid. This leaves politicians with little control over policy-making and service delivery. Through these reforms, private-sector principles are applied in the management of public institutions. The emphasis is on decentralization, cost saving, job cuts, performance-based rewards, and antitrade unionism. Because of a combination of external imposition and negative effects, the implementation of NPM reforms in developing countries is problematic. There is resistance from various sections of society, including members of the public and trade unions.

This article reveals that despite being negatively affected by NPM reforms, public-sector unions in developing countries are still active participants in the reform process. They do so by making strategic decisions to adapt to the changing circumstances. This revelation supports strategic choice theory which argues that the key actors affected by the reform of industrial relations make strategic choices to achieve their goals (Kochan et al., 1994). In this regard, the strategies of trade unions in developing countries are similar to those adopted by their counterparts in the developed world. The adoption of these strategies follows a threestage process. The first stage involves opposing the adoption and implementation of NPM reforms. This strategy takes the forms of denunciations, protests, strikes, and legal actions. However, this strategy cannot prevent the implementation of externally driven reforms. This is because of government's ability to use force to implement them especially when financial aid is at stake. Nonetheless, the strategy of opposing the reforms sets the foundation for trade unions to participate in the reform process. The second stage involves participating in the reform process and negotiating for reform measures that are more favorable to workers such as job protection and good compensation. 
The third stage involves changing the structures and operations of the union to mitigate the negative effects of the reforms. The changes are in four key areas. These are membership recruitment, union objectives, collective bargaining, and union governance. Under membership recruitment, the change is from closed to open unionism (i.e., rather than being confined to a particular occupation, recruitment is extended to workers in different occupations). In the case of union objectives, the focus is on serving the interests of a diversified membership rather than a homogeneous one. Under collective bargaining, the change is from centralized to decentralized bargaining. In the case of union governance, the change is from centralized structures to networks within and outside the union.

The crucial contribution of the present study has been to shed light on the still poorly understood responses of public-sector unions in the context of developing countries. Despite important differences to developed countries, specifically, the externally imposed nature of the reforms and the high vulnerability of public workers, these unions use strategies that can also be observed in developed countries to mitigate the negative consequences of NPM reforms on the public sector. Although this article has contributed to the literature on trade unionism under the rubric of NPM reforms, it does not cover the strategies of protecting the interests of a diversified membership. Therefore, future research can focus on open and expansive unionism in the context of NPM reforms.

\section{Declaration of Conflicting Interests}

The author(s) declared no potential conflicts of interest with respect to the research, authorship, and/or publication of this article.

\section{Funding}

The author(s) received no financial support for the research, authorship, and/or publication of this article. 


\section{References}

Anderson, E., Griffin, G., \& Teicher, J. (2002, December). The changing roles of public sector unionism (Working Paper No. 83). Melbourne, Australia: National Key Centre in Industrial Relations, Monash University.

Andrae, G., \& Beckman, B. (2011). Trade unions, tailors, and civil society. Labour, Capital and Society, 44(1), 18-42.

Ayee, J. R. A. (2008). Reforming the African public sector: Retrospect and prospects. Dakar, Senegal: Council for the Development of Social Science Research in Africa.

Bendix, S. (2010). Industrial relations in South Africa (5th ed.). Cape Town, South Africa: Juta.

Brewster, C., Dempsey, M., \& Hegewisch, A. (2001). The unions' response to change in the public sector. In B. C. Nolan (Ed.), Public sector reform: An international perspective (pp. 135-150). New York, NY: Palgrave Macmillan.

Christensen, T., \& Lægreid, P. (Eds.). (2007). Transcending new public management: The transformation of public sector reforms. Hampshire, UK: Ashgate.

Civil Servants and Allied Workers Union of Zambia. (n.d.). Constitution of the Civil Servants and Allied Workers Union of Zambia. Lusaka: Author.

Civil Servants' Union of Zambia. (1985). Constitution. Lusaka, Zambia: Government Printer. Cohen, N., \& Arieli, T. (2011). Field research in conflict environments: Methodological challenges and snowball sampling. Journal of Peace Research, 48, 423-435.

Connoley, R. M. (2008). Public sector reform agendas and outcomes for trade unions: The case of local government reform in Victoria, 1992-1999 (Doctoral thesis). Southern Cross University, Lismore, Australia.

Dzimbiri, L. B. (2008). Experiences in new public management in Africa: The case of performance management systems in Botswana. Africa Development, 33(4), 43-58.

Edigheji, O. (2008). Introduction: Public sector reforms and the quest for democratic developmentalism in Africa. Africa Development, 33(4), 1-13.

Heeks, R. (1998, July). Information systems and public sector accountability (Information Systems for Public Sector Management: Working Paper Series, Paper No. 1). Manchester, UK: Institute for Development Policy and Management, University of Manchester.

Hood, C. (1991). A public management for all seasons? Public Administration, 69, 3-19. Hughes, J. (1966). British trade unionism in the sixties. The Socialist Register, 3, 86113. Hyman, R. (1975). Industrial relations: A Marxist introduction. London, England: Macmillan.

Hyman, R. (1994). Changing trade union identities and strategies. In R. Hyman \& A. Ferner (Eds.), New frontiers in European industrial relations (pp. 108-139). Oxford, UK: Blackwell.

Kochan, T. A., Katz, H. C., \& McKersie, R. B. (1994). The transformation of American industrial relations. New York, NY: ILR Press, Cornell University.

Koyi, G. (2010). Collective bargaining in the public sector in Zambia: Report of baseline survey. Lusaka: LRS-CSAWUZ Project. 
Krishna, K. (2006). The impact of privatisation in resuscitating Zambia's economy. In J. C. Momba \& M. D. Kalabula (Eds.), Governance and public services delivery in Zambia (pp. 62-68). Lusaka: University of Zambia Press.

Lane, J.-E. (2000). New public management. London, England: Routledge.

Manning, N. (2001). The legacy of the new public management in developing countries. International Review of Administrative Sciences, 67, 297-312.

Martin, B. (1997, October). Reform of public sector management: A relevant question for unions in the public sector? Background paper for EPSU/ETUI Conference, Brussels, Belgium.

McCarthy, W. E. J. (Ed.). (1985). Trade unions: Selected readings (2nd ed.). Middlesex, UK: Penguin Books.

McDonald, D. A., \& Pape, J. (Eds.). (2002). Cost recovery and the crisis of service delivery in South Africa. Cape Town, South Africa: Human Sciences Research Council.

Momba, M. M. (2006). Administrative reforms and the search for efficient delivery of public service: The challenges facing health and education boards. In J. C. Momba \& M. D. Kalabula (Eds.), Governance and public services delivery in Zambia (pp. 4452). Lusaka: University of Zambia Press.

Mwambwa, S., Griffiths, A., \& Kahler, A. (2010). A fool's paradise? Zambia's mining tax regime (CTPD Policy Briefing Paper No. 1). Lusaka, Zambia: Centre for Trade Policy and Development.

Omoyefa, P. S. (2008). Public sector reforms in Africa: A philosophical re-thinking. Africa Development, 33(4), 15-30.

Pitcher, M. A. (2007). What has happened to organized labor in Southern Africa? International Labor and Working-Class History, 72, 134-160.

Pollitt, C., \& Bouckaert, G. (2011). Public management reform: A comparative analysisNew public management, governance, and the neo-Weberian state (3rd ed.). Oxford, UK: Oxford University Press.

Republic of Zambia. (1993). The Public Service Reform Programme (PSRP) (Volume IMain report; Volume II-Detailed review of the PSRP launch meeting held November 2-4, 1993, at the Inter-Continental hotel in Lusaka, Zambia). Lusaka, Zambia: Cabinet Office.

Republic of Zambia. (1996). The Privatisation Act: Chapter 386 of the laws of Zambia. Lusaka, Zambia: Government Printer.

Republic of Zambia. (2005). Public service management component: Final. Lusaka, Zambia: Cabinet Office.

Sakellaropoulos, S., \& Sotiris, P. (2014). Postcards from the future: The Greek debt crisis, the struggle against the EU-IMF austerity package and the open questions for left strategy. Constellations, 21, 262-273. doi:10.1111/1467-8675.12082

Salamon, M. (2000). Industrial relations: Theory and practice (4th ed.). Harlow, UK: Pearson Education.

Schnabel, C., Zagelmeyer, S., \& Kohaut, S. (2006). Collective bargaining structure and its determinants: An empirical analysis with British and German establishment data. European Journal of Industrial Relations, 12, 165-188. 
Simutanyi, N. (1996). The politics of structural adjustment in Zambia. Third World Quarterly, 17, 825-839.

Simutanyi, N. (2011). Political challenges facing the Zambian labour movement ahead of the 2011 general elections. In The labour movement in Zambia (pp. 19-25). Lusaka, Zambia: Friedrich-Ebert-Stiftung.

Streeck, W., \& Visser, J. (1997). The rise of the conglomerate union. European Journal of Industrial Relations, 3, 305-332.

Waddington, J. (2005, July). Trade union membership in Europe: The extent of the problem and the range of trade union responses. A background paper for the ETUC/ETUIREHS top-level summer school, Florence, Italy.

Webster, E. (2006). Trade unions and the challenge of the informalisation of work. In S. Buhlungu (Ed.), Trade unions and democracy: Cosatu workers' political attitudes in South Africa (pp. 21-43). Cape Town, South Africa: Human Sciences Research Council.

Zafra-Gómez, J. L., Bolívar, M. P. R., \& Muñoz, L. A. (2012). Contrasting new public management (NPM) versus post-NPM through financial performance: A cross-sectional analysis of Spanish local governments. Administration \& Society, 45, 710-747.

Zagelmeyer, S. (2007). Determinants of collective bargaining centralization: Evidence from British establishment data. Journal of Industrial Relations, 49, 227-245.

Zambia Privatisation Agency. (1999, July 1-December 31). Zambia Privatisation Agency: Progress report (No. 15). Lusaka: Author. 